\title{
Effect of cold temperature storage on the quality attributes of pawpaw and guava leathers
}

\author{
Babalola S. O. ${ }^{1}$, Ashaye O. A. ${ }^{2^{\star}}$, Babalola A. $0 .{ }^{1}$ and Aina J. O. ${ }^{3}$ \\ ${ }^{1}$ NIHORT, P.M.B 5342, idishin, Ibadan, Nigeria \\ ${ }^{2}$ I.A.R\&T, Obafemi Awolowo University, P. M. B. 5029, Ibadan, Nigeria \\ ${ }^{3}$ Department of Food Technology, University of Ibadan, Ibadan, Nigeria
}

Accepted 18 November 2002

\begin{abstract}
The effect of cold temperature storage on the quality attributes of pawpaw and guava leathers was evaluated. Pawpaw leather was significantly higher than guava leather in calorific content, water activity, $\mathrm{pH}$ and total mould count throughout the duration of storage. However Guava leather was higher in texture. Sensory scores in relation to period of storage showed that Guava leather gave better result in overall acceptability at zero, one and two months of storage at $8 \pm 1^{\circ} \mathrm{C}$. Guava leather also gave better sensory qualities in fruitiness, smell, chewiness, toughness, colour, and overall acceptability when varietal influence is considered. Guava leather is better accepted.
\end{abstract}

Key words: Pawpaw, guava sensory, leather, storage.

\section{INTRODUCTION}

Guava (Psidium guajava) is a fruit with sweet aroma and a pleasant sour-sweet taste. The fruit can be freshly eaten or cooked. It can also be used in the preparation of jellies and jams. It contains moisture $(82 \%)$, protein $(7 \%)$ and carbohydrate (11\%) (Samson, 1986). Pawpaw (Carica papaya) is a popularly fruit in the tropics. It has a pleasant sweet taste and flavour and has a great application in the preparation of fruit salads and deserts. Pawpaws also have a mild laxative action and the seeds are used medicinally against worms. When unripe it can be fermented into sauerkraut or cooked as a substitute for applesauce (Foyet, 1972). It contains moisture $(85 \%)$, sugar $(10-13 \%)$ and protein $(0.6 \%)$. There has been a greater increase in the production rate of these fruits over the years, and this may be due to their increased consumption pattern in the tropics (FAO, 1983). These fruits are known to attract low prices in major markets in Nigeria.

Fruit leather is very popular in the North American market and not well known in the tropical countries like Nigeria. It is manufactured by dehydrating a fruit puree into a leather sheet (Raad and Oehler, 1976), which is eaten as a sauce or as a confection (Cruess, 1969).

*Corresponding author; e-mail: kayodeashaye@softhome.net
Leathers can be made from a wide variety of fruit including pawpaw, guava, banana and sweet potato (Collins and Hatsell, 1987). There is a dearth of information on the stability of pawpaw and guava leathers during storage at cold temperature. Therefore, this study was initiated to investigate the quality attributes of pawpaw and guava leathers at such conditions.

\section{MATERIALS AND METHODS}

Fresh fruits of pawpaw (pink solo) and guava (A1habad) were obtained from National Horticultural Research Institute (NIHORT) Idi-Ishin in Ibadan, Nigeria. To prepare guava and pawpaw leathers, the fresh fruits were peeled and a solution of $20 \%$ sugar, $0.2 \%$ citric and $0.1 \%$ sodium benzoate was added to a concentration of $80 \%$ of the pulp. It was then boiled, cooled and spread on trays that have been previously oiled with glycerol. Drying was carried out at $60^{\circ} \mathrm{C}$ for $8 \mathrm{hrs}$ before packaging and storing at cold temperature condition $8 \pm 1^{0} \mathrm{C}$ for a period of 2 months. Texture, $\mathrm{pH}$, water activity $\left(\mathrm{a}_{\mathrm{w}}\right)$, and calorific content were analysed using standard techniques (AOAC, 1970). The leather samples were also evaluated by 10 panelists under a well-lighted room (Larmond, 1977) using a nine-point hedonic scale basis $(1=$ dislike extremely and $9=$ 
Table 1. Physicochemical and microbiological properties of pawpaw and guava leathers stored for 2 months at cold temperature condition $\left(8 \pm 1^{\circ} \mathrm{C}\right)$.

\begin{tabular}{lcccccc}
\hline Sample & $\begin{array}{l}\text { Period of } \\
\text { Storage } \\
\text { (Months) }\end{array}$ & $\begin{array}{l}\text { Calorific } \\
\text { content } \\
(\text { Kca1/100g) }\end{array}$ & $\mathrm{a}_{\mathrm{w}}$ & $\begin{array}{l}\text { Texture } \\
(\text { Kgf })\end{array}$ & $\mathrm{PH}$ & $\begin{array}{l}\text { Total mould } \\
\text { count } \\
\text { (Calories/g) }\end{array}$ \\
\hline $\begin{array}{l}\text { Pawpaw } \\
\text { Leather }\end{array}$ & 0 & $336.40^{\mathrm{a}}$ & $0.73^{\mathrm{a}}$ & $0.46^{\mathrm{b}}$ & $6.37^{\mathrm{b}}$ & $36.67^{\mathrm{a}}$ \\
& 1 & $335.33^{\mathrm{a}}$ & $0.72^{\mathrm{ab}}$ & $0.45^{\mathrm{b}}$ & $6.63^{\mathrm{a}}$ & $31.33^{\mathrm{b}}$ \\
$\begin{array}{l}\text { Guava } \\
\text { Leather }\end{array}$ & 0 & $335.65^{\mathrm{a}}$ & $0.71^{\mathrm{b}}$ & $0.45^{\mathrm{b}}$ & $6.50^{\mathrm{ab}}$ & $26.00^{\mathrm{c}}$ \\
& 1 & $331.35^{\mathrm{b}}$ & $0.64^{\mathrm{c}}$ & $0.61^{\mathrm{a}}$ & $5.43^{\mathrm{c}}$ & $33.67^{\mathrm{b}}$ \\
& 2 & $330.72^{\mathrm{b}}$ & $0.63^{\mathrm{cd}}$ & $0.61^{\mathrm{ce}}$ & $5.27^{\mathrm{d}}$ & $25.00^{\mathrm{c}}$ \\
\hline
\end{tabular}

Means in the same column followed by the same letter are not significantly from each other at $\mathrm{P}<0.05$.

Table 2. Effect of period of storage on the sensory attributes of Guava and Pawpaw leather stored at $8 \pm 1^{0} \mathrm{C}$.

\begin{tabular}{|c|c|c|c|c|c|c|c|c|}
\hline Months & Sample & Sweetness & Fruitiness & Smell & Chewiness & Toughness & Colour & $\begin{array}{c}\text { Overall } \\
\text { Acceptability }\end{array}$ \\
\hline \multirow[t]{2}{*}{0} & Guava & $5.6^{a}$ & $6.8^{\mathrm{a}}$ & $6.6^{\mathrm{a}}$ & $7.0^{\mathrm{a}}$ & $7.0^{\mathrm{a}}$ & $6.8^{\mathrm{a}}$ & $6.8^{\mathrm{a}}$ \\
\hline & Pawpaw & $6.6^{a}$ & $5.0^{b}$ & $5.0^{b}$ & $4.8^{\mathrm{b}}$ & $4.8^{\mathrm{b}}$ & $4.6^{\mathrm{b}}$ & $5.0^{b}$ \\
\hline \multirow[t]{2}{*}{1} & Guava & $6.0^{\mathrm{a}}$ & $6.2^{\mathrm{a}}$ & $5.8^{\mathrm{a}}$ & $7.4^{\mathrm{a}}$ & $7.8^{\mathrm{a}}$ & $6.0^{\mathrm{a}}$ & $7.0^{\mathrm{a}}$ \\
\hline & Pawpaw & $6.4^{\mathrm{a}}$ & $5.0^{\mathrm{a}}$ & $5.2^{\mathrm{a}}$ & $5.6^{\mathrm{b}}$ & $5.4^{\mathrm{b}}$ & $5.2^{\mathrm{a}}$ & $5.2^{\mathrm{b}}$ \\
\hline \multirow[t]{2}{*}{2} & Guava & $6.2^{\mathrm{a}}$ & $7.6^{\mathrm{a}}$ & $5.6^{\mathrm{a}}$ & $7.6^{\mathrm{a}}$ & $7.6^{\mathrm{a}}$ & $5.2^{\mathrm{a}}$ & $6.8^{\mathrm{a}}$ \\
\hline & Pawpaw & $6.8^{\mathrm{a}}$ & $5.8^{\mathrm{b}}$ & $5.4^{\mathrm{a}}$ & $4.8^{\mathrm{b}}$ & $4.8^{\mathrm{b}}$ & $4.8^{\mathrm{a}}$ & $5.0^{\mathrm{b}}$ \\
\hline
\end{tabular}

Means in the same column followed by the letter are not significantly different from each other at $\mathrm{P}<0.05$.

like extremely). Water was provided for the tasters to rinse their month after each assessment. Data were subjected to analysis of variance and Duncan multiple range test (Duncan, 1955).

\section{RESULTS AND DISCUSSION}

The calorific content of pawpaw leather was significantly higher than guava leather, but there was no significant change in the calorific content of pawpaw leather throughout the duration of storage (Table 1). The high calorific content of pawpaw leather could be due to its higher carbohydrate content and therefore it can be considered as a good source of energy. There was a decrease in water activity of both pawpaw and guava leather with increased storage, which could be attributed to moisture loss. It was also observed that guava leather has a significantly higher texture than pawpaw leather. This may be due to differences in their genetic make up, rate of water absorption and protein content 
(Cheman et al., 1995; Samson, 1986). The $\mathrm{pH}$ of pawpaw leather stored for one month at cold temperature condition was significantly higher than other samples. While the $\mathrm{pH}$ of guava leather at one and two months of storage were significantly lower when compared with others. These differences can be due to fermentation by microorganisms. The total mould counts decreased with increase in storage time for both pawpaw and guava leathers. This trend may be due to the residual effect of sodium benzoate acting as antimycotic agent.

Guava leather was significantly higher than pawpaw leathers in fruitiness, smell, chewiness, toughness colour and overall acceptability at zero month of storage at $8 \pm$ $1^{\circ} \mathrm{C}$. After two months of storage, guava leather was scored higher in fruitiness, chewiness, toughness and overall acceptability (Table 2). In terms of sweetness, however, pawpaw leather was rated higher than guava leather.

\section{REFERENCES}

AOAC (1970). Official Methods of Analysis, 11th edition Association of official Analysis chemists Washington, DC.

Cheman YB, Taufik (1995). Development and Stability of jack fruit leather. Trop. Sci. 35:245-250.

Collins JL, Hutsell LW (1987). Physical, Chemical, Sensory and Microbiology attributes of sweet potato leather. J. Food Sci. 52:646648.

Cruess WV (1969). Commercial fruit and vegetable products 4th Ed. New York: Mc Graw-Hill.

Duncan DB (1955). Multiple range and Multiple F tests Biometrics, vol. 11 No. 1 , pp. $1-5$.

FAO (1983). Production yearbook 1982, Rome.

Foyet M (1972). L' extraction de la papaine. Fruits 27:30-36.

Larmond $E$ (1977). Laboratory methods for sensory evaluation of food. Publication 1284, Canadian Department of Agriculture, Ottawa, Canada.

Raab C, Oehler N (1976). Making dried fruit leather fact sheet 232. Oregon state University Ext Service.

Samson JA (1986). Tropical fruits. Longman group, UK, p. 2. 